\title{
Short Communication: Species composition and growth performance of mangrove forest at the coast of Tanah Merah, East Nusa Tenggara, Indonesia
}

\author{
RONGGO SADONO ${ }^{1, \bullet}$, DJOKO SOEPRIJADI ${ }^{1}$, ARI SUSANTI ${ }^{1}$, PANDU YUDHA ADI PUTRA WIRABUANA ${ }^{1}$, \\ JERIELS MATATULA, ${ }^{2, \downarrow}$ \\ ${ }^{1}$ Department of Forest Management, Faculty of Forestry, Universitas Gadjah Mada. Jl. Agro No. 1, Bulaksumur, Sleman 55281, Yogyakarta, Indonesia \\ Tel./fax.: +62-274-548815, `email: rsadono@ugm.ac.id \\ ${ }^{2}$ Forestry Field Program, Politeknik Pertanian Negeri Kupang. Jl. Prof. Herman Johanes, Lasiana, Kupang 85011, East Nusa Tenggara, Indonesia. \\ Tel./fax.: +62-380-881600, ^^email: jerielsforestry@gmail.com
}

Manuscript received: 26 October 2020. Revision accepted: 26 November 2020.

\begin{abstract}
Sadono R, Soepriadi D, Susanti A, Wirabuana PYAP, Matatula J. 2020. Short Communication: Species composition and growth performance of mangrove forest at the coast of Tanah Merah, East Nusa Tenggara, Indonesia. Biodiversitas 21: $5800-5804$. The availability of information about species composition and growth performance of mangrove forests is required to determine the best strategies for sustainable ecosystem management, particularly in the coastal area. This study aimed to quantify the species composition and growth performance of mangrove stand established at the coast of Tanah Merah, East Nusa Tenggara. Forest inventory was conducted using nine permanent sampling plots which evenly distributed in zonations of mangrove. Data were collected in different life stages of vegetation, namely seedling, sapling, pole, and tree. Several parameters were calculated to describe species composition, including importance value index, richness, heterogeneity, and evenness. Four indicators were selected to assess the growth performance of mangrove stand in this location, i.e. mean diameter, average height, timber volume, and wood biomass. Results demonstrated the species composition of mangrove forest consisted of 9 different plants. The highest importance value index of seedling was noted in A. marina (124.09) while the highest importance value index of sapling (86.57), pole (130.01), and tree (118.58) were recorded in S. alba. This location had low level of richness (1.22) and heterogeneity (0.88) but having high level of evenness (0.99). The mean diameter and height of mangrove stand in this area were $15.2 \mathrm{~cm}$ and $8.3 \mathrm{~m}$ with an average timber volume and wood biomass around $90.7 \mathrm{~m}^{3} \mathrm{ha}^{-1}$ and $65.1 \mathrm{Mg} \mathrm{ha}^{-1}$ respectively. Based on these findings, we suggested to conduct enrichment planting for improving plant diversity of mangrove forest at the coast of Tanah Merah.
\end{abstract}

Keywords: Enrichment planting, heterogeneity, plant diversity, richness, sustainable mangrove management

\section{INTRODUCTION}

The presence of mangrove forests has an important contribution to providing environmental services in coastal areas such as windbreak, preventing abrasion, and averting sea-water intrusion (Matatula et al. 2019). This ecosystem is also a habitat for a number of sea organisms that have high economic value, such as fish, shrimps, and crabs (Sihombing et al. 2017). A study also explains that mangrove forest is a source of profitable non-timber forest products, like tannins and ecotourism (Kusmana and Sukristijiono 2016). Moreover, the existence of mangrove forests has a meaningful function related to climate change mitigation by reducing carbon emissions in the atmosphere (Taillardat et al. 2018). Therefore, the practice of sustainable ecosystem management in mangrove forest has become an interesting challenge in many archipelago countries, including Indonesia.

As one of the tropical countries, Indonesia has 4.5 million hectares of mangrove forest equivalent to $23 \%$ of the global mangrove ecosystem which is proportionally distributed in every province (Richards and Friess 2016; Susilo et al. 2017). However, the majority of mangrove forests in Indonesia are degraded due to the impact of human activities, such as land-use change and environmental pollution (Ilman et al. 2016). Consequently, most mangrove forests cannot provide optimum functions for supporting environmental services in the coastal area. It also results in negative impact for communities who live around coastal areas. These circumstances have encouraged people to conduct reforestation in mangrove ecosystems. However, the practice of mangrove reforestation is not easy since it requires high participation of communities as the primary key to guarantee the success of reforestation program (Eddiwan 2018). During the last period, there were many coastal areas that had initiated implementation of mangrove reforestation. Unfortunately, only a few areas were successful to achieve the objective, one of them is a coastal area located in Tanah Merah, East Nusa Tenggara.

The activity of mangrove reforestation in Tanah Merah has been started intensively since 2004 by a collaboration between local communities and District government. Since 2004 this effort has added more than 100 hectares of mangrove forest cover in the area (Sadono et al. 2020). Nevertheless, the results of mangrove reforestation particularly related to its species composition and growth performance of stand in this area have been rarely documented. On another side, the available information 
about those variables is necessary to determine the best strategies for sustainable management in mangrove ecosystems. Thereby, this study aimed to quantify the number of species composition and growth performance of mangrove stand established at the coast of Tanah Merah, East Nusa Tenggara. The results are expected to provide adequate information about species diversity and stand productivity of mangrove ecosystems in this site.

\section{MATERIALS AND METHODS}

\section{Study area}

This study was undertaken in mangrove forest located at the coast of Tanah Merah. It had total area of approximately 120 hectares. This site had geographic coordinates in $10^{\circ} 5^{\prime} 43^{\prime \prime}-10^{\circ} 7^{\prime} 48^{\prime \prime} \quad S$ and 123 $43^{\prime} 13^{\prime \prime}-$ $123^{\circ} 44^{\prime} 48^{\prime \prime}$ E. The mangrove forest of Tanah Merah was classified as the region of Kupang District. This area had dry conditions with annual rainfall around 1,500 $\mathrm{mm}_{\text {year }}{ }^{-1}$. Topography was dominated by flat area with slope levels varying from $0-3 \%$. Dry periods were relatively longer than 6 months.

\section{Procedures}

This study was categorized as survey experiment in which it was designed to measure the characteristics of mangrove forest at the coast of Tanah Merah. Forest inventory was done in April 2020 using nine permanent sampling plots with size $50 \mathrm{~m} \times 50 \mathrm{~m}$ (Figure 2). The sampling plot was placed systematically to represent the environmental gradient of mangrove forests. The distance of every plot was $100 \times 100 \mathrm{~m}$. In each permanent sampling plot, five circular sub-plots were set up at five different positions, i.e. 4 sub-plots at the corner and 1 subplots at the center. The radius of circular sub-plots was 17.8 m. In every sub-plots, several measurement plots were made with different radius for facilitating the measurement of vegetation, namely seedling (1m), sapling $(2 \mathrm{~m})$, and pole $(5 \mathrm{~m})$. Meanwhile, the measurement of tree was carried out in every circular sub-plots. The measured parameters for seedling and sapling were type of species and density while the observed parameters for pole and tree were type of species, density, diameter at breast height, and height.

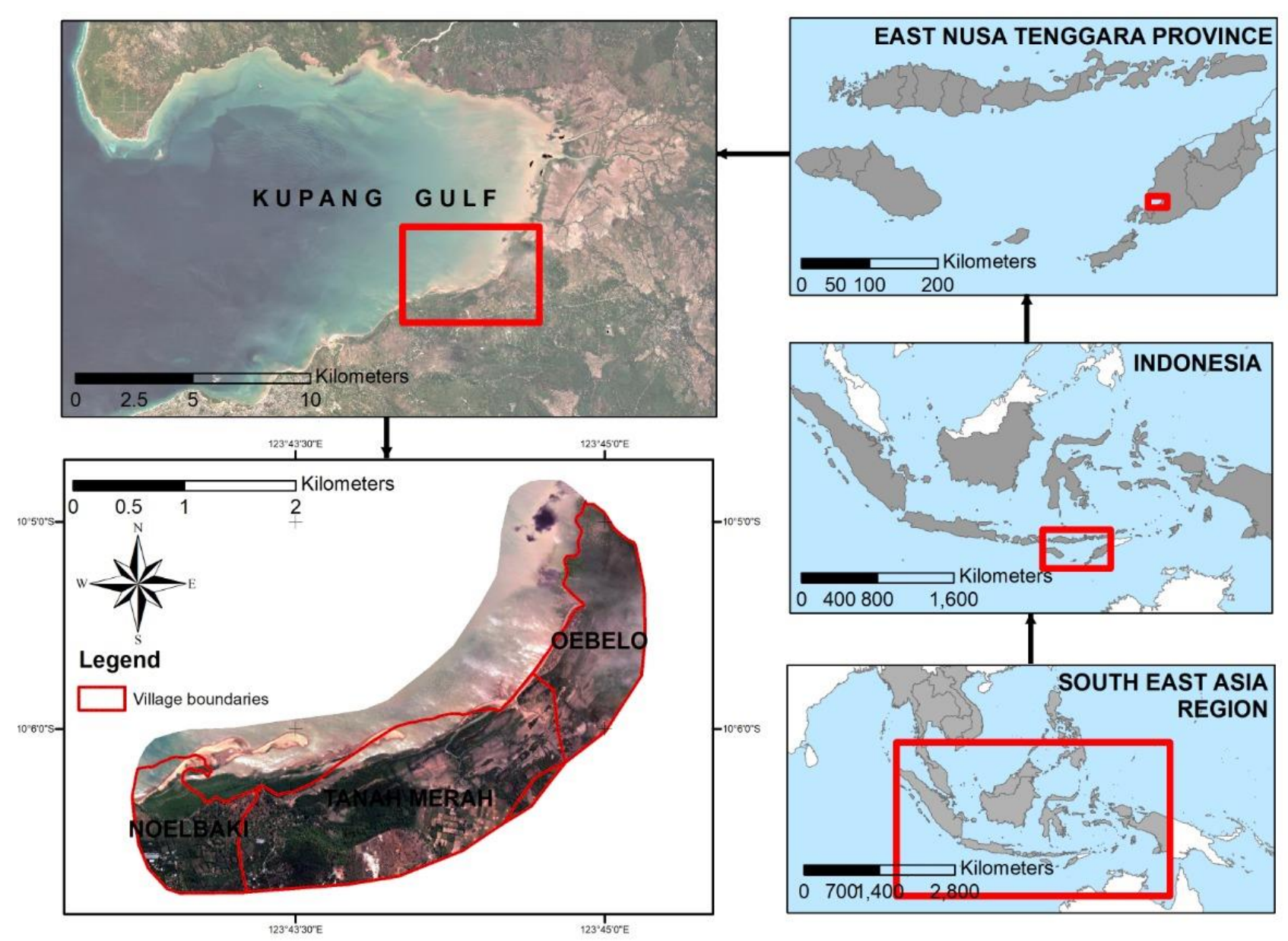

Figure 1. Location of mangrove forests at the coast of Tanah Merah, East Nusa Tenggara Province, Indonesia. The study area was located between Noelbaki and Oebelo (Sadono et al. 2020) 


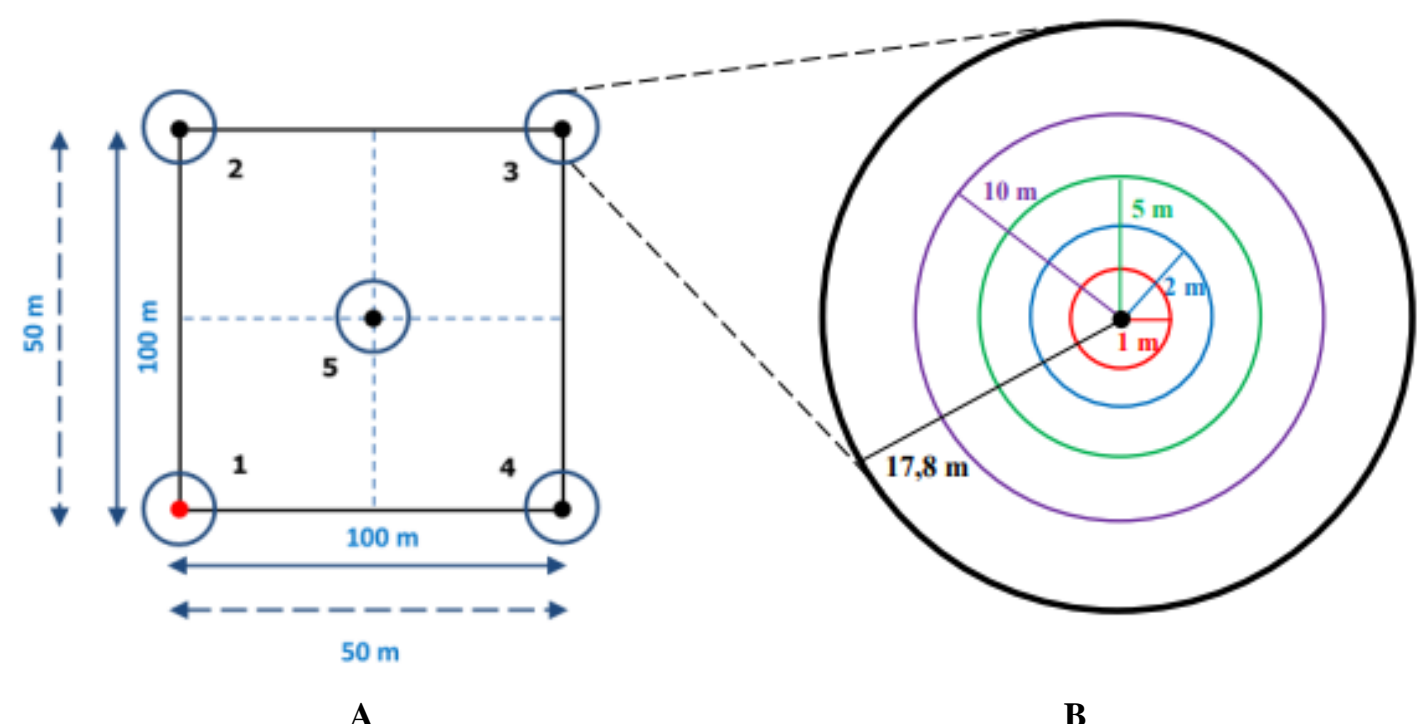

Figure 2. Design of permanent sampling plot for facilitating forest inventory in the mangrove area: A. Shape of permanent sampling plot with size $50 \mathrm{~m} \times 50 \mathrm{~m}$; B. Shape of circular sub-plots for vegetation measurement (Source: Regulation of the Directorate General of Forestry Planning and Environmental Management No. P.1/PTKTL/IPSDH/PLA.1/1/2017 concerning about Technical Guidelines Forest Inventory in Protected Forest Management Units and Production Forest Management Units)

\section{Data analysis}

Vegetation data were processed to derive the species density (individual ha $\left.{ }^{-1}\right)$, dominance $\left(\mathrm{m}^{2} \mathrm{ha}^{-1}\right)$, and frequency (\%) (Eddy et al. 2019). The importance value index (IVI) for each stage of vegetation was determined by the relative value of density, dominance, and frequency (Kasim et al. 2019). The diversity of mangroves was evaluated using three indicators, i.e. richness (Margalef index), heterogeneity (Shanno-Wienner Index), and evenness (Pielou index) (Singh 2020). The diversity was calculated at tree stage since this life form was relatively more stable than others. The growth performance of mangrove stand was quantified by several parameters, including average diameter, mean height, timber volume, and wood biomass. Individual timber volume and wood biomass in every species were calculated with following equations:

$$
\begin{aligned}
& \mathrm{V}=0.25 \pi \mathrm{D}^{2} \mathrm{H} \\
& \mathrm{B}=\mathrm{V} \text { WD }
\end{aligned}
$$

Where; $V$ was individual tree volume, $D$ indicated diameter at breast height, $H$ signified tree height, $B$ was wood biomass in stem, and $W D$ describes wood density for every mangrove species (Muhd-Ekhzarizal et al. 2018).

\section{RESULTS AND DISCUSSION}

Summarized results of the observation demonstrated there were 9 different plant species which constructed mangrove ecosystems at the coast of Tanah Merah, including Acanthus ilicifolius, Acrostichum aureum, Aegialitis annulata, Avicennia marina, Lumnitzera littorea, L. racemosa, Rhizophora stylosa, Sonneratia alba, and $S$. caseolaris (Table 1). Interestingly, the distribution of species in every life form of vegetation was relatively different. For example, our study only recorded four species in saplings but found five species in seedling, pole, and tree. The existence of A. ilicifolius, A. aureum, and A. annulata was only noted in seedlings while the presence of L. racemosa was only discovered in tree stage. However, A. marina was frequently observed in every stage of vegetation.

The different species distribution in every stage of vegetation was possibly caused by several factors such as history of management and plant competition. Referring to the previous study of Sadono et al (2020), it was clearly noted that mangrove ecosystem at the coast of Tanah Merah was a result of reforestation. In this case, the plant materials for supporting reforestation relatively varied in every period since it was difficult to obtain specific species with enough quantity. The various species in every life stage could be also caused by the occurrence of plant competition for obtaining resources (Padilla et al. 2004). The high plant competition would accelerate natural mortality for weaker species in every type of ecosystem. 
Table 1. Life stage-wise species composition and Importance value index in mangrove ecosystems at the coast of Tanah Merah

\begin{tabular}{lcccc}
\hline \multirow{2}{*}{ Species } & \multicolumn{4}{c}{ Life stage of mangrove vegetation } \\
\cline { 2 - 5 } & Seedling & Sapling & Pole & Tree \\
\hline Acanthus ilicifolius & 14.58 & & & \\
Acrostichum aureum & 15.48 & & & \\
Aegialitis annulata & 30.96 & & & \\
Avicennia marina & 124.09 & 52.57 & 111.51 & 74.70 \\
Lumnitzera littorea & & 26.29 & 16.53 & 52.92 \\
Lumnitzera racemosa & & & & 40.68 \\
Rhizophora stylosa & 14.88 & 34.57 & 24.75 & \\
Sonneratia alba & & 86.57 & 130.01 & 118.58 \\
Sonneratia caseolaris & & & 17.20 & 13.12 \\
Total & 200 & 200 & 300 & 300 \\
Presence count & 5 & 4 & 5 & 5 \\
\hline
\end{tabular}

In the concept of forest ecology, including mangrove ecosystems, the important position of species could be identified based on the rank of importance value index (IVI) (Eddy et al. 2019). Higher IVI indicated greater contribution of species in ecosystems (Yuliana et al. 2019). This study found that the most important species in seedling level was occupied by A. marina with IVI of 124.09 (Table 1). Surprisingly, the most essential species in sapling, pole, and tree were recorded in $S$. alba with IVI of 86.57, 130.01, and 118.58 respectively. A. marina and $S$. alba become the most dominant species in this ecosystem since the availability of plant materials of both species were relatively high and easy to find for using in reforestation programs. Our statement was also supported by the previous study reported by Sadono et al. (2020) which described the history of mangrove reforestation in Tanah Merah.

Our study realized that diversity of mangrove forests in Tanah Merah was relatively very low since it had the level of species richness and heterogeneity for each around 1.22 and 0.81. As per Djufri et al. (2016), diversity could be classified based on the value of species heterogeneity $\left(\mathrm{H}^{\prime}\right)$. In general, the $\mathrm{H}^{\prime}$ value typically ranged from 0 to 7 wherein $H^{\prime}<1$ was categorized as very low diversity; H' 1-2 was classified as low diversity; H' 2-3 was grouped as medium diversity; H' 3-4 was classed as high diversity, and $\mathrm{H}^{\prime}>4$ was clustered as very high diversity. Despite it had very low diversity, the distribution of mangrove species in this area was relatively even with having evenness index 0.99 . This result indicated the mangrove forest in this area was not managed in monoculture systems. Kvålseth (2015) explained the range of evenness index was 0-1 wherein if the index was closer to 1 , it indicated the plant communities in the ecosystems was not homogenous

This study observed the growth performance of mangrove forest at the coast of Tanah Merah highly varied for every species (Table 2). The highest species productivity was recorded in L. littorea $\left(36.5 \pm 10.1 \mathrm{~m}^{3} \mathrm{ha}^{-}\right.$ ${ }^{1}$ ) followed by $S$. alba $\left(26.1 \pm 0.4 \mathrm{~m}^{3} \mathrm{ha}^{-1}\right)$, A. marina (13.9 $\left.\pm 0.2 \mathrm{~m}^{3} \mathrm{ha}^{-1}\right)$, L. racemosa $\left(12.6 \pm 0.4 \mathrm{~m}^{3} \mathrm{ha}^{-1}\right), R$. stylosa $\left(0.11 \pm 0.01 \mathrm{~m}^{3} \mathrm{ha}^{-1}\right)$, as well as $S$. caseolaris $(0.11 \pm 0.01$ $\left.\mathrm{m}^{3} \mathrm{ha}^{-1}\right)$. Despite having similar timber volume, the productivity of $R$. stylosa was relatively higher than $S$. caseolaris since this species resulted in greater wood biomass. Overall, the average productivity of mangrove forests in Tanah Merah was $89.5 \pm 1.9 \mathrm{~m}^{3} \mathrm{ha}^{-1}$ with the mean wood biomass of $64.2 \pm 1.4 \mathrm{Mg} \mathrm{ha}^{-1}$.

The different growth performance of species in mangrove was common due to inter-specific competition. However, this study observed that the variation of growth in this area was more influenced by the different age of stand. It was confirmed by the study from Sadono et al. (2020) that documented the process of mangrove reforestation in Tanah Merah. According to the study, the planting period of mangroves in this area exceptionally varied due to influence of sea tide dynamics.

In conclusion, this study noted the diversity of mangrove forests in Tanah Merah was very low even though it consisted of nine different species. The average productivity of mangrove stand in this location was $89.5 \pm$ $1.9 \mathrm{~m}^{3} \mathrm{ha}^{-1}$ with the mean wood biomass of $64.2 \pm 1.4 \mathrm{Mg}$ $\mathrm{ha}^{-1}$. Based on these results, it is suggested to conduct enrichment planting for improving plant biodiversity of mangrove forest at the coast of Tanah Merah.

\section{ACKNOWLEDGEMENTS}

We are grateful to the Faculty of Forestry, Gadjah Mada University, Yogyakarta, Indonesia for providing financial support for this study. We also express our gratitude to the East Nusa Tenggara government for permitting us to conduct this study in Kupang, Indonesia.

Table 2. Growth performance of every specie in mangrove ecosystems at the coast of Tanah Merah

\begin{tabular}{lllll}
\hline \multicolumn{1}{c}{ Species } & \multicolumn{1}{c}{$\mathbf{D}(\mathbf{c m})$} & $\mathbf{H}(\mathbf{m})$ & $\mathbf{V}\left(\mathbf{m}^{\mathbf{3}} \mathbf{h a} \mathbf{-}^{-\mathbf{1}}\right)$ & $\mathbf{B}\left(\mathbf{M g ~ h a} \mathbf{- 1}^{-\mathbf{1}}\right.$ \\
\hline Avicennia marina & $12.5 \pm 5.1$ & $8.4 \pm 2.4$ & $13.9 \pm 0.2$ & $10.2 \pm 0.1$ \\
Lumnitzera littorea & $46.1 \pm 49.9$ & $7.7 \pm 2.3$ & $36.5 \pm 10.1$ & $26.5 \pm 7.2$ \\
Lumnitzera racemosa & $28.6 \pm 8.7$ & $7.5 \pm 3.1$ & $12.6 \pm 0.4$ & $10.5 \pm 0.3$ \\
Rhizophora stylosa & $6.7 \pm 0.4$ & $8.3 \pm 1.0$ & $0.11 \pm 0.01$ & $0.10 \pm 0.01$ \\
Sonneratia alba & $13.5 \pm 6.2$ & $8.3 \pm 2.8$ & $26.1 \pm 0.4$ & $16.8 \pm 0.2$ \\
Sonneratia caseolaris & $10.2 \pm 3.8$ & $6.3 \pm 0.4$ & $0.11 \pm 0.01$ & $0.05 \pm 0.02$ \\
Total Species & $19.6 \pm 12.4$ & $7.8 \pm 2.0$ & $89.72 \pm 1.9$ & $64.2 \pm 1.4$ \\
\hline
\end{tabular}

Note: $\mathrm{D}$ (average diameter at breast height), $\mathrm{H}$ (mean height), $\mathrm{V}$ (timber volume), and B (wood biomass) 


\section{REFERENCES}

Djufri, Wardiah, Muchlisin ZA. 2016. Plants diversity of the deforested peat-swamp forest of Tripa, Indonesia. Biodiversitas 17: 372-376. DOI: $10.13057 /$ biodiv/d170150.

Eddiwan K. 2018. Success level of mangrove tree planting real in Kepulauan Meranti district, Riau, Indonesia. J Aquac Mar Biol 7: 213-218. DOI: 10.15406/jamb.2018.07.00211.

Eddy S, Ridho MR, Iskandar I, Mulyana A, 2019. Species composition and structure of degraded mangrove vegetation in the Air Telang Protected Forest, South Sumatra, Indonesia. Biodiversitas 20: 21192127. DOI: $10.13057 /$ biodiv/d200804.

Ilman M, Dargusch P, Dart P, Onrizal. 2016. A historical analysis of the drivers of loss and degradation of Indonesia's mangroves. Land use policy 54: 448-459. DOI: 10.1016/j.landusepol.2016.03.010.

Kasim F, Kadim MK, Nursinar S, Karim Z, Lamalango A. 2019 Comparison of true mangrove stands in Dudepo and Ponelo islands, North Gorontalo district, Indonesia. Biodiversitas 20: 359-366. DOI 10.13057/biodiv/d200142.

Kusmana C, Sukristijiono S, 2016. Mangrove resource uses by local community in Indonesia. J Nat Resour Environ Manag 6: 217-224. DOI: $10.19081 /$ jpsl.2016.6.2.217.

Kvålseth TO. 2015. Evenness indices once again: critical analysis of properties. Springerplus 4: 232. DOI: 10.1186/s40064-015-0944-4.

Matatula J, Poedjirahajoe E, Pudyatmoko S, Sadono R. 2019. Spatial distribution of salinity, mud thickness and slope along mangrove ecosystem of the coast of Kupang District, East Nusa Tenggara, Indonesia. Biodiversitas 20: 1624-1632. DOI 10.13057/biodiv/d200619.

Muhd-Ekhzarizal ME, Mohd-Hasmadi I, Hamdan O, Mohamad-Roslan MK, Noor-Shaila S. 2018. Estimation of aboveground biomass in mangrove forests using vegetation indices from SPOT-5 image. J Trop For Sci 30: 224-233. DOI: 10.26525/jtfs2018.30.2.224233.
Padilla C, Fortes MD, Duarte CM, Terrados J, Kamp-Nielsen L. 2004 Recruitment, mortality and growth of mangrove (Rhizophora sp.) seedlings in Ulugan Bay, Palawan, Philippines. Trees 18: 589-595. DOI: $10.1007 / \mathrm{s} 00468-004-0351-\mathrm{x}$

Richards DR, Friess DA, 2016. Rates and drivers of mangrove deforestation in Southeast Asia, 2000-2012. Proc Natl Acad Sci USA 113: 344-349. DOI: 10.1073/pnas.1510272113.

Sadono R, Soeprijadi D, Susanti A, Matatula J, Pujiono E, Idris F, Wirabuana PYAP. 2020. Local indigenous strategy to rehabilitate and conserve mangrove ecosystem in the southeastern Gulf of Kupang, East Nusa Tenggara, Indonesia. Biodiversitas 21: 1250-1257. DOI: 10.13057/biodiv/d210353.

Sihombing VS, Gunawan H, Sawitri R. 2017. Diversity and community structure of fish, plankton and benthos in Karangsong mangrove conservation areas, Indramayu, West Java, Indonesia. Biodiversitas 18: 601-608. DOI: 10.13057/biodiv/d180222.

Singh JK. 2020. Structural characteristics of mangrove forest in different coastal habitats of Gulf of Khambhat arid region of Gujarat, west coast of India. Heliyon 6: e04685. DOI: 10.1016/j.heliyon.2020.e04685.

Susilo H, Takahashi Y, Yabe M. 2017. The opportunity cost of labor for valuing mangrove restoration in Mahakam Delta, Indonesia. Sustainability 9: 2169. DOI: 10.3390/su9122169.

Taillardat P, Friess DA, Lupascu M. 2018. Mangrove blue carbon strategies for climate change mitigation are most effective at the national scale. Biol Lett 14: 20180251. DOI: 10.1098/rsbl.2018.0251.

Yuliana E, Hewindati YT, Winata A, Djatmiko WA, Rahadiati A. 2019. Diversity and characteristics of mangrove vegetation in Pulau Rimau Protection Forest, Banyuasin District, South Sumatra, Indonesia. Biodiversitas J Biol Divers 20: 1215-1221. DOI: 10.13057/biodiv/d200438. 